\title{
"Kangaroo generations": New contexts, new experiences
}

\author{
"Gerações-canguru": novos contextos, \\ novas experiências
}

\begin{abstract}
The aim of the article is to discuss academic productions published over the last 25 years regarding the transition to adulthood and focusing on the "Kangaroo generation". We found that these studies managed to recognize the pluralization and the single character of the transition to adulthood, with the parent-child living together, which is not necessarily associated with a dysfunctional character. We believe that the kangaroo family is a possible domestic arrangement that does not necessarily set doubts about the adult condition of the children. We propose the plural term "kangaroo generations" with the purpose of broadening the meaning of cohabitation between parents and children during the "mature stage" of the family life cycle. In addition, we consider that the level of knowledge derived from these studies cannot bring us satisfying notions of what it means to be an adult in the contemporary world and the notion of adulthood lacks revision, which makes further studies necessary.
\end{abstract}

Keywords: Adult; Family; Life cycle stages.

\section{Resumo}

Este artigo dialoga com produções acadêmicas dos últimos 25 anos acerca da transição para a vida adulta, com foco na "geração canguru". Constatou-se que os estudos evoluíram quanto a reconhecer a pluralização e a singularização das trajetórias de construção da adultez, passando a coabitação parento-filial a ser compreendida como possibilidade inscrita nesse contexto, desvinculada de um caráter necessariamente disfuncional. Acredita-se ser a família canguru uma possibilidade de arranjo doméstico que não coloca, obrigatoriamente, dúvidas quanto à condição adulta dos filhos. Propõe-se o termo plural "gerações-canguru" como forma de ampliar o olhar sobre os significados da coabitação entre pais e filhos na fase madura do ciclo vital familiar. Além disso, considera-se que o nível de conhecimento ora possibilitado é insuficiente para oferecer noções satisfatórias do que é ser adulto na contemporaneidade, permanecendo a ideia de adultez carente de revisão, tornando necessárias novas pesquisas.

Palavras-chave: Adulto; Família; Estágios do ciclo de vida.

\section{$\boldsymbol{\nabla} \nabla \boldsymbol{\nabla}$}

1 Pontifícia Universidade Católica de São Paulo, Faculdade de Ciências Humanas e da Saúde, Programa de Estudos Pós-Graduados em Psicologia Clínica. R. Monte Alegre, 984, 4º andar, sala 4E 05, Perdizes, 05014-901, São Paulo, SP, Brasil. Correspondência para/Correspondence to: I. KUBLIKOWSKI. E-mail: <kubli.i@terra.com.br>.

Support: Plano de Incentivo à Pesquisa and Publicação de Artigos from Pontifícia Universidade Católica de São Paulo (Process $\left.\mathrm{n}^{\circ} 502,2015\right)$. 
The psychosocial aspects of the transition to adulthood have been the object of new studies and broader discussions that address youth both understood as a stage in life (Pais, 2009) and a lifestyle (Szapiro \& Resende, 2010). Until the mid1970s, the traditional academic view, in agreement with normative Psychology, understood the life cycle as a universal sequence of stages that were marked by ruptures during the stages of transition. These ruptures, as normative crisis, were considered as a satisfactory turning point if new structural equilibrium was reached based on pre-established solutions, with an emphasis on the process of adaptation (Erikson, 1998).

The theory of stages postulated wellestablished identities in constant scenarios, which remained recursively. The norm, which justified certain ways of living and offered instructions about how individuals should grow up, resulted in the creation of a social reality of the processes that Developmental Psychology sought to explain (Bruner, 1996). The "scientific discoveries", once absorbed into the culture, ended up creating real expectations, shaping the participants of society and outlining the reality that they intended to describe.

Currently, the weakness of such a perspective, challenged by different authors (Arnett, 2005; Borges \& Magalhães, 2009; Pais, 2009; Pimenta, 2007; Rodrigues, 2011; Szapiro \& Rezende, 2010), establishes multiple possible routes and meanings for the experience of becoming an adult. The developmental process is inscribed within family relationships. The contemporary family, due to profound contextual changes, presents itself under different arrangements and dynamics, which exposes the relativity of values and the inadequacy of traditional models to define it.

Yet, it is still possible to analyze the family life cycle due to the regularities that can be observed throughout life, as members of different families share societal expectations that cannot be neglected when addressing how people perceive themselves and behave (Falicov, 1991). As Keith and Whitaker (1991) pointed out, the concept of life cycle does not represent the life cycle of any particular family, systems and dialoguing with them, provided that this dialogue does not become inflexible.

We observe, then, a trend in which normative models are replaced by local and temporal processes, not as priori entities, but rather as entities that are constructed, supported and challenged in communication processes. Developmental Psychology, which has traditionally emphasized change regarding universality, repetition and predictability, is modified in contemporary Psychology to embrace the unexpected and to open space for developments with a sense of novelty and creativity.

It is characterized as a systemic view of the processes and meanings of experience, a view that is expanded to contemplate the complexity and that recognizes, in the process of family development across the life cycle, the instability and unpredictability of changes in the system, as well as the role of intersubjectivity in the construction of reality (Vasconcellos, 2009).

Conceiving the social world by means of an idea of interrelated systems that replaces the idea of an object reducible to elementary units implies accepting that the phenomenon involves biological and cultural aspects expressed in personal narratives, entangled in family and social histories at a given time and space. The notion of the developmental process, which articulates the life cycle of the individual and family within a particular context through circular and recursive relationships, eventually supplants the traditional idea of linear causality (Morin, 1977). In this sense, the prospect of the life cycle of the family cannot be conceived as a condition to classify families within the parameters of normality, as a context of profound social change falls on family organization and ultimately makes it harder to construct life trajectories due to the lack of models.

A particular view on the transition from adolescence to adulthood illustrates these changes. As Rodrigues (2011) points out, the prolonging of the permanence of adult children in the parental home leads to new trends in the family life cycle. As the labor market demands from the youth higher education and training, amid a plurality of choices 
and awareness of the risks involved, the idea of adulthood as a fully organized and stable state is challenged. This, in accordance with Debert (2010), would result in a blurring of the boundaries between age groups in a society that praises youth and the youth lifestyle, and in which risk, instability and experimentation are strongly present in older age groups.

The finding that the permanence of older children in the parental home can be observed nationwide confirms the relevance of the topic. The "Synthesis of Social Indicators", based on the 2012 Pesquisa Nacional de Amostra por Domicílio (PNAD, National Household Sample Survey), released by the Instituto Brasileiro de Geografia e Estatística (2012) (Brazilian Institute of Geography and Statistics), shows that, in the southeast region, the proportion of young people between the ages of 25 and 34 years living with their parents has increased from $23.1 \%$ in 2002 to $26.7 \%$ in 2012. In Brazil, this proportion rose from $20.5 \%$ in 2002 to $24.3 \%$ in 2012. These young people have, on average, 11.4 years of education, compared with the national average of 9.6 years. Moreover, in the southeast, $31.9 \%$ of people aged 60 or more live with their children older than 25 years of age.

Nationally, $60.0 \%$ of the population between the ages of 25 and 34 years who remain in the parental home are men; $94.5 \%$ of these men and women in the southeast are placed in the labor market, of which $91.4 \%$ are within this age group. This family composition is more common in families whose income ranges from two to more than five minimum wages (30.0\%) compared with households whose per capita income is less than half a minimum wage $(6.6 \%)$.

Furthermore, the study of Macedo and Kublikowski (2014) on the life cycle of Brazilian families in urban middle classes found among respondents that $30.6 \%$ of children between the ages of 26 and 35 years live with their parents. Of these same families, $62.4 \%$ stated having no difficulties cohabiting with their children. These are significant numbers if we consider that these parents had been brought up in a traditional culture of normality which, during their transition to adulthood, valued marriage, parenthood, self-support and leaving parental home as criteria for confirming adulthood.

\section{Dialoguing with different authors}

This research results from studies that have been conducted around the theme of transition to adulthood (Rodrigues, 2011). We conducted a nonsystematic review of academic papers published over the last 25 years with a critical eye on normality established by traditional Developmental Psychology. We searched Google Scholar and Scientific Electronic Library Online (SciELO) using the descriptors "young adult", "kangaroo generation" and "youth" and consulted classical texts on the individual and family life cycle.

In addressing these academic productions around the passage to adulthood in the contemporary world, we found descriptions of this period, such as the one proposed by Aylmer (1995), who names it "the launching of the young single adult" and defines this period through tasks, among which he includes: leaving the family home and facing the challenge of being in the adult world, becoming financially independent, marrying and having children. However, in view of the new social reality that enables unique life trajectories, marriage and parenthood are no longer a traditional requirement, but an option or further choice. In turn, financial independence can now be considered from a more relative perspective, since those families in which the children are placed in the labor market and have a reasonable financial income do not express the desire to leave the parental home, which parents, at the same time, do not see as a problem.

From a more normative view, Jablonski and Martino (2013) argue that remaining in the parental home maintains the young adults dependent, making it difficult for them to take up social commitments, maintaining them in the perpetual condition of adolescents. Concurrently, other studies point out that unfulfilled family chores throughout the life cycle hinder the youth's physical and emotional emancipation (Vieira \& Rava, 2012). We understand that although these realities are possible, 
generalizing and describing kangaroo-families as dysfunctional implies establishing these unfulfilled family chores as traditional markers of the passage to adulthood, ignoring the possibility of new forms of family organization.

From the perspective of the parents, the definition of young adults is complemented by the definition of middle-age people, proposed by McCullough and Rutenberg (1995), who call this phase "launching children and moving on". The authors describe changes in marriage and parenting roles. They point out that in-laws and grandchildren broaden the family system relationships, change the relationships of parents with their genitors in the process of aging, during which illnesses and death may require the redefinition of relationship networks. Depression can also result from the empty nest, as well as the recreation of life projects during which one may seek new opportunities and roles, for example, through work.

However, Kublikowski (2001) suggests pondering on the above-mentioned description, since the "empty nest syndrome", which has haunted the lives of women for decades, was not mentioned by the group studied by the researcher. The author claims that the emptying of the parental home, along the mature stage of the family life cycle, is a phenomenon that loses strength whether as a result of the prolonged cohabitation between parents and their offspring or because the divorced children return to the family home, often accompanied by grandchildren.

We should also point out that the Brazilian home, as stated by Cerveny and Berthoud (2009), unlike American, is usually full for a longer time, possibly due to the family values such as protection and care. Borges and Magalhães (2009) point out, in this regard, the importance of the parental home as a space that enables both "individualized and hierarchized practices" (p.48), allowing the construction and the exercise of autonomy, supported by a network of affection, respect and solidarity. The idea of "launching children" loses strength and nourishes the conditions for the existence of the "kangaroo generation". Ferreira, Rezende, and Lourenço (2011) also point out the individualization of life trajectories as a contemporary phenomenon that favors the permanence of children in the parental home, emphasizing the following economic dimension: when children live with the parents for a longer period of time, they may be able to "save money, invest in a career, or maintain a desired level of consumption" (p.14).

Silveira and Wagner (2006) approach the full nest from the perspective of the youngsters and conclude that the difficulties in finding work and earning better wages, as well as the desire to continue to enjoy the comfort and safety of the parental home, motivate them to stay at their parent's home. Vieira and Rava (2010) suggest changes in the time of departure of the children as a transition from an empty nest to a crowded nest, a phenomenon that is more evident in the middle class urban population, which lead us to an understanding of this phenomenon within its context.

Brandão, Saraiva, and Matos (2012) point out that the prolongation of the youth condition in Europe, in the United States and in the SouthAmerican countries enables us to identify trends that justify the emergence of a new adult status, particularly within a certain social strata. According to the authors, the transition to adulthood is prolonged to the beginning of the third decade of life and it is characterized by the postponement of marriage, increase in mean age of the first born child, and longer school careers, with its consequently later placement in the labor market. Also according to the research, staying in the parental home becomes an opportunity for experience and personal investment, which becomes possible with parental support, due to financial difficulties and inplacement in professional positions that would allow the reproduction of the social status of the family. Hence, this experience would be related to the socioeconomic structures of each country in which, both in the Mediterranean and South American countries, family values and the absence of policies supporting emancipation favor the emergence of these possible passages to adulthood. Thus, people's biographic trajectory that could be interpreted as experiences of greater freedom from 
social constraints find their counterpart in possible choices within new structural possibilities.

The same research points out, however, that care must be taken not to generalize this experience, which is specific to a population stratum, as we might end up classifying theyouth from disadvantaged backgrounds as non-normative. We believe that family organization is based on three axes: gender, generation, and socioeconomic status. Since 60\% of young people between the ages of 25 and 34 years living in the parental home are men, the following issues about gender, which are rarely addressed in the academic productions we have reviewed, need to be analyzed: changes in the values related to intimacy relationships, and the massive placement of women in the labor market, seem to ascribe new features to the transition to adulthood. Combining novelty (greater possibilities for economic independence) with tradition (education that also includes home care), women seem to be at greater ease to leave the parental home than men. Moreover, as discussed above, the permanence of adult children living with their parents associated with the increase in the years of education, which is possible in families whose income is sufficient to provide for larger investments in education, postpone or even override objectives such as marriage and having children.

\section{Kangaroo generations}

The term "kangaroo generation" has been used to describe families in which the children remain cohabiting with parents, even after reaching an age when they could be considered adults. The origin of the term lies in the animal kingdom and it is related to the species of mammals called marsupials (from the Latin term marsupium, meaning bag), which carry their offspring in a ventral pouch while the premature offspring completes its development (Ferreira, 1999). Therefore, we must point out that, based on the idea of the experience of development of joeys that remain together with the mother, the conception of "kangaroo generation" that we suggest is that of children who remain in, or return to, the parental home, in order to get some kind of financial or emotional parental support during the process of transition to adult life, or even when they have reached adulthood. In this paper, we add the term "kangaroo family", using it as a synonym for "kangaroo generation", as we believe that human development is characterized by a complementary relationship that involves parents and children.

Based on the above-mentioned conception of "kangaroo generation", it is important to point out the socioeconomic dimension that it defines. That is, particularly in Brazil, it is not uncommon in lower-income families for the children, even after being married and having children, to remain living with their parents, either in the same physical environment or in the so-called "puxadinhos" (dwellings built on the parent's property). Considering the limited possibilities of change, this refers to a physical organization motivated by economic needs that financially benefits both parents and their children. From a systemic point of view in Psychology, we seek to discuss human emotional development from a relational perspective, hence the importance of considering the issues involved in cohabitation between parents and potentially adult children at a stage of the family life cycle in which, traditionally and normatively, there used to be expectations of physical separation. However, it is worth stating an important research question: in which way is the process of transition to adulthood influenced by socioeconomic, or ethnic and cultural, factors?

So far, few academic studies have focused on the children's own view of the kangaroo generation. Still, we realize that some studies that have approached the issue (adult children living with parents) included families that, according to our understanding, could be regarded as dysfunctional (Vieira \& Rava, 2012) or did not include a significant number of individuals to validate the understanding about the adult situation of the kangaroo children (Silveira \& Wagner, 2006). Above all, the aim of these studies was not to present data that stated the self-concept of these children regarding their adulthood. We emphasize the need for further research, which is already being conducted, to 
consider the perspective of the individuals own identity during the transition to adulthood.

However, we have noticed that some studies have given valuable contributions to the relational dynamics regarding the cohabitation of parents and adult children. In a study conducted with parents and their children, Henriques, Féres-Carneiro, and Ramos (2011) indicate the existence of a silent game in which disagreements and consensus end up redefining the rules of coexistence, which, in turn, have a positive effect on the individual experiences of members of the household. Considering the relational patterns that separate hierarchy from satisfaction and mutual respect, the interaction between parents and children during the mature stage of the family life cycle (Cerveny \& Berthoud, 2009) does not seem to oppress the potential autonomy of children.

Borges and Magalhães (2009, p.48), in turn, identify the family as an important support network for children during the transition to adulthood, in view of a minimum of State support in contemporary societies that, within a context that values autonomy, generates helplessness. Staying at the parents' home can be seen, according to the authors, as a "relationship of solidarity between generations", showing a "mismatch between individual practices and models adopted by institutions that mediate collective life". Recognizing the functionality of the horizontal nature of relationships regarding the cohabitation of parents and adult children, the authors go beyond the pathological perspective of those studies that, while maintaining the traditional markers of transition to adulthood, attribute the condition of eternal teenagers to kangaroo children.

A research conducted by Rodrigues (2011), which addresses the parents' perspective on the issue, shows that they accept the relativity of obligation, among the children, to ritualize the transition to adulthood through marriage, financial independence and leaving from the parental home. Thus, although the construction of the "adult" is still family-centered, a pre-defined trajectory is far less expected, but rather it has become a process guided by moral values of responsibility and
Another blind spot in studies that deal with the transition to adulthood in contemporary times is the disregard of those who could be called the "kangaroos out of the pouch". Clinical experience suggests that many parents in high-income families subsidize their children's residence that, in turn, although living outside the parental home, are still financially and sometimes emotionally dependent on their parents. It is clear, therefore, that we need to broaden our perspectives to include the realities present in the daily lives of urban strata, and particularly to give voice to those who can, being an adult or not, par excellence, speak for themselves.

Given the above-mentioned reality of academic productions that clearly state the risk of restricting the kangaroo-families to tight realities, we deem appropriate to broaden our perspectives and consider that the existence of "kangaroo generations" is consistent with the distinct realities of the families. We do not ignore the existence of families in which cohabitation between parents and potentially adult children may occur within dysfunctional family dynamics. However, we believe that this is not the only possible reality.

\section{Final Considerations}

Reading some of the academic productions over the last twenty-five years regarding the transition to adulthood and the phenomenon of the "kangaroo generation", we noticed that many authors have difficulty in recognizing that, within a context marked by the complexity and instability of reality, privileging one sense of normality in developmental Psychology can turn into a dangerous tool for the concept of what it is to be an adult nowadays. We also noticed their difficulty in conceiving the relativization of the importance of the traditional markers for the transition to adulthood, despite the recognition oft he pluralization of the possible trajectories of the young and their different experiences while constructing their adult identity

With regard to the kangaroo families, we believe that we need to consider the uniqueness of 
life trajectories in contemporary life, which is an aspect acknowledged by those authors who have separated cohabitation between parents and children from the pathological hallmark. Furthermore, we consider that if, on one hand, the requirement of these traditional markers of passage into the adult world should be revised, on the other hand we need to listen to what those individuals, par excellence, have to say about themselves: individuals who, living with her parents or not, experience the process of transition to adulthood.

The creation of terms such as "emerging adulthood" and "young adult" and the proposition of youth as a stage in life are signs of recognition, in the academia, that social meanings attributed to adulthood are no longer rigid and new perspectives are open. However, we still believe that these new constructs only postpone the recognition of early adulthood, for they acknowledge that the markers of the passage to adulthood have taken longer to consolidate. This notion seems to be a problem especially for the kangaroo families in which the prolongation of cohabitation between parents and children in the urban middle strata is often seen as a period of preparation for an autonomous life which would be "truly" adult. Will it always be so? Would these children be living with their parents necessarily in order to consolidate their developmental processes?

In this sense, instead of using the term "kangaroo generation", we chose to use the plural "kangaroo generations", in order to broaden the view of the possibilities of construction of life trajectories in contemporary times. In our study, we seek to avoid the stigmatization of kangaroo families as dysfunctional families and particularly kangaroo children as eternal teenagers.

\section{Contributors}

Both authors contributed for the conception and design of the study, data analysis, and final writing.

\section{References}

Arnett, J. J. (2005). Emerging adulthood: Understanding the new way of coming of age. In J. J. Arnett \& J. L.
Tanner (Eds.), Emerging adults in America: Coming of age in the $21^{\text {st }}$ century (pp.3-19). Washington: American Psychological Association.

Aylmer, R. C. (1995). O lançamento do jovem adulto solteiro. In B. Carter \& M. McGoldrick, As mudanças no ciclo de vida familiar: uma estrutura para a terapia familiar (pp.169-183). Porto Alegre: Artmed.

Borges, C. C., \& Magalhães, A. S. (2009). Transição para a vida adulta: autonomia e dependência na família. Psico, 40(1), 42-49.

Brandão, T., Saraiva, L., \& Matos, P. M. (2012). O prolongamento da transição para a idade adulta e o conceito de adultez emergente: especificidades no contexto português e brasileiro. Análise Psicológica, 30(3), 301-313.

Bruner, J. (1996). Realidad mental y mundos posibles: los actos de la imaginación que dan sentido a la experiencia. Barcelona: Gedisa.

Cerneny, C. M. O., \& Berthoud, C. E. M. (2009). Ciclo vital da família brasileira. In L. C. Osório \& M. E. P. Valle. Manual de terapia familiar (pp.25-37). Porto Alegre: Artmed.

Debert, G. G. (2010). A dissolução da vida adulta e a juventude como valor. Horizontes Antropológicos, 16(34), 49-70.

Erikson, E. H. (1998). O ciclo de vida completo. Porto Alegre: Artes Médicas.

Falicov, C. J. (1991). Contribuciones de la sociología de la familia y de la terapia familiar al "esquema del desarrollo familiar": análisis comparativo y reflexiones sobre las tendencias futuras. In C. J. Falicov (Comp.), Transiciones de la familia: continuidad y cambio en el ciclo de vida (pp.3-51). Buenos Aires: Amorrortu.

Ferreira, A. B. H. (1999). Novo dicionário Aurélio. Rio de Janeiro: Nova Fronteira.

Ferreira, P. A., Rezende, D. C., \& Lourenço, C. D. S. (2011). Geração canguru: algunas tendências que orientam o consumo jovem e modificam o ciclo de vida familiar. Espacios, 32(1), 12-14.

Henriques, C. R., Féres-Carneiro, T., \& Ramos, E. (2011). Ajustes entre pais e filhos adultos coabitantes: limite e transgressão. Psicologia em Estudo, 16(4), 531-539.

Instituto Brasileiro de Geografia e Estatística. (2012). Pesquisa Nacional por Amostra de Domicílios: síntese de indicadores 2012. Recuperado em março 6, 2014, de http://www.ibge.gov.br/home/estatistica/populacao/ trabalho erendimento/pnad2012/default_sintese.shtm

Jablonsky, J. F., \& Martino, F. (2013). A qualitative exploration of emerging adults' and parents' perspectives on communicating adulthood status. The Qualitative Report, 18(73), 1-12.

Keith, D. V., \& Whitaker, C. A. (1991). La presencia del pasado: continuidad y cambio em la estrucutura simbólica de las famílias. In C. J. Falicov (Comp.), 
Transiciones de la familia: continuidad y cambio en el ciclo de vida (pp.589-610). Buenos Aires: Amorrortu.

Kublikowski, I. (2001). A meia idade feminina em seus significados: o olhar da complexidade (Tese de doutorado não-publicada). Pontifícia Universidade Católica de São Paulo.

Macedo, R. M. S., \& Kublikowski, I. (2014, Maio). Ciclo vital dos estratos médios de famílias urbanas no Brasil. Relatório de Pesquisa apresentado no XV Simpósio de Pesquisa e Intercâmbio Científico da ANPEPP, Bento Gonçalves, Rio Grande do Sul.

McCullough, P., \& Rutemberg, S. (1995). Lançando os filhos e seguindo em frente. In B. Carter \& $M$. McGoldrick. As mudanças no ciclo de vida familiar: uma estrutura para a terapia familiar (pp.248-268). Porto Alegre: Artmed.

Morin, E. (1977). O método 1: a natureza da natureza. Portugal: Publicações Europa-América.

Pais, J. M. (2009). A juventude como etapa da vida: dos ritos de passagem aos ritos de impasse. Saúde e Sociedade, 18(3), 371-381.

Pimenta, M. M. (2007). Ser jovem e ser adulto: identidade, representações e trajetórias (Tese de doutorado não-publicada). Universidade de São Paulo.
Rodrigues, C. M. (2011). Processos de transição para a vida adulta: do olhar dos pais a uma compreensão intergeracional (Dissertação de mestrado não-publicada). Pontifícia Universidade Católica de São Paulo.

Silveira, P. G., \& Wagner, A. (2006). Ninho cheio: a permanência do adulto jovem em sua família de origem. Estudos de Psicologia (Campinas), 23(4), 431-453. http://dx.doi.org/10.1590/S0103-166X2006000 400012

Szapiro, A. M., \& Resende, C. M. A. (2010). Juventude: etapa da vida ou estilo de vida? Psicologia \& Sociedade, 22(1), 43-49.

Vasconcellos, M. J. E. (2009). Pensamento sistêmico: o novo paradigma da ciência. Campinas: Papirus.

Vieira, A. C. S., \& Rava, P. G. S. (2010). Ninho cheio: uma nova etapa do ciclo vital familiar? Barbaroi, 33, 118134.

Vieira, A. C. S., \& Rava, P. G. S. (2012). Ninho cheio: perspectivas de pais e filhos. Psicologia: Teoria e Prática, 14(1), 84-96.

Received: April 29, 2014

Final version: October 10, 2014

Approved: October 30, 2014 